\title{
14. PARTITION GEOCHEMISTRY OF SEDIMENTS FROM HOLES 506 AND 509B, DEEP SEA DRILLING PROJECT LEG 701
}

\author{
S. P. Varnavas, Department of Geology, University of Patras, Patras, Greece \\ and \\ S. A. Moorby and D. S. Cronan, A.G.R.G., Department of Geology, Imperial College of Science and Technology, \\ London SW7 2BP, England
}

\begin{abstract}
Partition geochemical analyses have been carried out on sediment samples from two Leg 70 mounds holes (Holes 506 and 509B) for the elements $\mathrm{Fe}, \mathrm{Mn}, \mathrm{Ca}, \mathrm{Mg}, \mathrm{Al}, \mathrm{Co}, \mathrm{Ni}, \mathrm{Cu}, \mathrm{Zn}$, and $\mathrm{Pb}$. Significant variations occur in the partitioning of elements in the different lithologies recognized and also with depth in each hole. In particular, amounts of acid-reducible $\mathrm{Mn}$ and $\mathrm{Fe}$ increase upward in the uppermost 8 to 10 meters of sediment in each hole while acetic-acid soluble $\mathrm{Mn}$ increases in the lower half of each hole. The trace metals $\mathrm{Co}, \mathrm{Ni}, \mathrm{Cu}, \mathrm{Zn}$, and $\mathrm{Pb}$ show no recognizable patterns of variation with depth. The similarities in element-partition patterns with depth in the two holes studied suggest that similar conditions have been maintained at both sites during mounds formation, and the vertical partition pattern of Mn supports the theory of participation of buried Mn-oxides in nontronite formation.
\end{abstract}

\section{INTRODUCTION}

In recent years, partition geochemistry has become a useful method of investigating marine sediments. This technique involves determination of the proportional distribution of elements in the various phases of the sediments, and it can be achieved by leaching the sediments with different reagent solutions (Goldberg and Arrhenius 1958; Chester and Hughes, 1967; Cronan, 1976).

In this chapter we use the techniques of partition geochemistry to investigate Deep Sea Drilling Project (DSDP) Leg 70 sediment samples from two mounds holes, 506 and 509B.

\section{METHODS}

The partition analysis procedure used in this work is that described by Cronan (1976). The reagents used were acetic acid, hydroxylamine$\mathrm{HCl}$, and $\mathrm{HCl}$. The acetic acid attack essentially dissolves carbonates; the hydroxylamine- $\mathrm{HCl}$ reduces $\mathrm{Fe}-\mathrm{Mn}$-oxides, and the $\mathrm{HCl}$ dissolves crystalline $\mathrm{Fe}$-oxides and attacks clay minerals. The residue from the $\mathrm{HCl}$-attack consists largely of resistant silicates and aluminosilicates. Analysis of the leachates was carried out on an ARL 34000 inductively coupled argon plasma spectrograph for the following elements: Mn, $\mathrm{Fe}, \mathrm{Co}, \mathrm{Ni}, \mathrm{Cu}, \mathrm{Zn}, \mathrm{Pb}, \mathrm{Al}, \mathrm{Ca}$, and $\mathrm{Mg}$.

\section{ANALYTICAL RESULTS}

Tables 1 and 2 show the average partitioning of elements in the main sediment types recognized in Holes 506 and 509B. A description of these sediments is given in Moorby and Cronan (this volume). The variations within each sediment type will be described.

\section{Manganese-rich Sediments}

Manganese, $\mathrm{Fe}$, and $\mathrm{Al}$ show very similar partitioning in Mn-oxide crusts from both Holes 506 and 509B.

\footnotetext{
${ }^{1}$ Honnorez, J., Von Herzen, R. P., et al., Init. Repts. DSDP, 70: Washington (U.S. Govt. Printing Office)
}

However, crusts from Hole 509B have a higher $\mathrm{Ca}$ and $\mathrm{Mg}$ content, and higher percentages of the respective totals of these elements are acetic acid-soluble, suggesting the presence of more carbonate material in the samples from Hole 509B. The trace metals generally show significant variations in partitioning between crusts from the two sites. In particular, higher percentages of the respective totals of $\mathrm{Co}, \mathrm{Ni}, \mathrm{Cu}, \mathrm{Zn}$, and $\mathrm{Pb}$ are acid-reducible in Hole 506 crusts, although the total $\mathrm{Co}$ and $\mathrm{Ni}$ contents of the latter are lower than in Hole 509B samples, making the difference small in absolute terms. In crusts from Hole 509B, more $\mathrm{Co}, \mathrm{Ni}, \mathrm{Zn}$, and $\mathrm{Pb}$ is instead in the $\mathrm{HCl}$-resistant fraction while more $\mathrm{Cu}$ is in the $\mathrm{HCl}$-soluble fraction. These differences are probably not explainable in terms of different amounts and fractional solubilities of detrital impurities in the crusts at the two sites since the $\mathrm{Al}$ contents and $\mathrm{Al}$ partitioning are similar in crusts at both sites.

At Site 509B a Mn-rich mud occurs (see site reports and Moorby and Cronan, this volume). Samples of this mud were analyzed and its partition geochemistry compared with that of the Mn-oxide crust from the same hole. The results are also given in Table 2 .

While the partitioning of $\mathrm{Mn}$ is the same in both Mncrusts and muds, there is more $\mathrm{Fe}$ in the muds than in the crusts and a greater percentage of it is $\mathrm{HCl}$-soluble. Calcium is also higher in the muds than the crusts and more of it is acetic-acid soluble, reflecting the presence in the muds of appreciable amounts of calcium carbonate. By contrast there is more $\mathrm{Mg}$ in the crusts than in the muds and much more of it is acid-reducible, indicating a strong association with the Mn-oxides. Aluminosilicate material is also more abundant in the muds than in the crusts, as evidenced by the higher $\mathrm{Al}$ content of the former and its predominance in the $\mathrm{HCl}$-soluble and $\mathrm{HCl}$-resistant fractions. The trace metals $\mathrm{Co}, \mathrm{Ni}$, and $\mathrm{Pb}$ show little variations in content or partitioning although the total $\mathrm{Pb}$ content of the crusts is somewhat 
Table 1. Averaged partition geochemical data for sediments from Hole 506.

\begin{tabular}{|c|c|c|c|c|c|c|c|c|c|c|c|c|}
\hline Sediment Type & $\begin{array}{c}\text { No. of } \\
\text { Samples } \\
\text { Analyzed }\end{array}$ & Fraction & $\mathrm{Mn}$ & $\mathrm{Fe}$ & $\mathrm{Ca}$ & $\mathrm{Mg}$ & Al & Co & $\mathrm{Ni}$ & $\mathrm{Cu}$ & $\mathrm{Zn}$ & $\mathrm{Pb}$ \\
\hline \multirow[t]{5}{*}{ Mn-oxide crusts } & 2 & A & $<1$ & $<1$ & 25 & 19 & 2 & 0 & 4 & 17 & 12 & $<1$ \\
\hline & & B & 100 & 29 & 14 & 63 & 43 & 84 & 79 & 69 & 48 & 88 \\
\hline & & $\mathrm{C}$ & 0 & 23 & 2 & 5 & 23 & 5 & 8 & 7 & 6 & 2 \\
\hline & & D & 0 & 47 & 60 & 12 & 32 & 5 & 8 & 6 & 35 & 9 \\
\hline & & E & 48.4 & 0.40 & 0.77 & 1.75 & 0.19 & 10 & 113 & 50 & 82 & 166 \\
\hline \multirow[t]{5}{*}{ Nontronite } & 9 & $\mathrm{~A}$ & 20 & 1 & 51 & 14 & 3 & 14 & 30 & 30 & 8 & 15 \\
\hline & & B & 22 & 2 & 34 & 10 & 7 & 36 & 28 & 52 & 24 & 13 \\
\hline & & $\mathrm{C}$ & 47 & 92 & 1 & 70 & 53 & 25 & 41 & 16 & 37 & 10 \\
\hline & & D & 12 & 5 & 13 & 6 & 37 & 25 & 0 & 2 & 30 & 61 \\
\hline & & $\mathrm{E}$ & 0.12 & 18.7 & 0.76 & 2.1 & 0.15 & 11 & 32 & 19 & 52 & 30 \\
\hline \multirow{5}{*}{$\begin{array}{r}\text { Transitional } \\
\text { sediment }\end{array}$} & 4 & A & 45 & 1 & 84 & 29 & 2 & n.d. & 33 & 22 & 9 & 16 \\
\hline & & B & 12 & 2 & 8 & 4 & 3 & n.d. & 12 & 31 & 17 & 7 \\
\hline & & C & 30 & 93 & 3 & 67 & 77 & n.d. & 54 & 31 & 56 & 6 \\
\hline & & D & 12 & 7 & 6 & 0 & 18 & n.d. & 0 & 16 & 17 & 71 \\
\hline & & E & 0.14 & 13.0 & 11.2 & 1.9 & 0.62 & n.d. & 66 & 27 & 87 & 37 \\
\hline \multirow{5}{*}{$\begin{array}{l}\text { Surface pelagic } \\
\text { sediment }\end{array}$} & 1 & A & 8 & 6 & 80 & 54 & 6 & 11 & 39 & 56 & 43 & 50 \\
\hline & & B & 80 & 18 & 0 & 0 & 3 & 67 & 40 & 7 & 10 & 50 \\
\hline & & C & 12 & 50 & 7 & 37 & 60 & 22 & 21 & 36 & 28 & 0 \\
\hline & & D & 0 & 26 & 12 & 10 & 32 & 0 & 0 & 0 & 19 & 0 \\
\hline & & E & 1.1 & 1.4 & 29.0 & 0.52 & 1.0 & 9 & 108 & 85 & 144 & 16 \\
\hline
\end{tabular}

Note: $\mathrm{A}=$ acetic-acid soluble fraction; $\mathrm{B}=$ hydroxylamine $\mathrm{HCl}$ and acetic-acid soluble fraction; $\mathrm{C}=\mathrm{HCl}$-soluble fraction; $\mathrm{D}=\mathrm{HCl}$-resistant fraction. Values in rows A-D are percentages of the total amount (given in row E) which is soluble in each leach. $\mathrm{E}=$ bulk chemical composition $(\mathrm{Mn}, \mathrm{Fe}, \mathrm{Ca}, \mathrm{Mg}$, and $\mathrm{Al}$ in wt.\%; $\mathrm{Co}, \mathrm{Ni}, \mathrm{Cu}, \mathrm{Zn}$, and $\mathrm{Pb}$ in $\mathrm{ppm}) ; \mathrm{n} . \mathrm{d} .=$ not determined.

Table 2. Averaged partition geochemical data for sediments from Hole 509B. ${ }^{\mathrm{a}}$

\begin{tabular}{|c|c|c|c|c|c|c|c|c|c|c|c|c|}
\hline Sediment Type & $\begin{array}{c}\text { No. of } \\
\text { Samples } \\
\text { Analyzed }\end{array}$ & Fraction & Mn & $\mathrm{Fe}$ & $\mathrm{Ca}$ & $\mathrm{Mg}$ & $\mathrm{Al}$ & Co & $\mathrm{Ni}$ & $\mathrm{Cu}$ & $\mathrm{Zn}$ & $\mathrm{Pb}$ \\
\hline \multirow[t]{5}{*}{ Mn-oxide crust } & 2 & A & 3 & 1 & 49 & 39 & 6 & 0 & 14 & 21 & 21 & 1 \\
\hline & & B & 97 & 23 & 14 & 48 & 34 & 67 & 56 & 55 & 17 & 72 \\
\hline & & C & 0 & 34 & 5 & 7 & 29 & 9 & 12 & 21 & 4 & 6 \\
\hline & & D & 0 & 41 & 31 & 5 & 30 & 23 & 19 & 2 & 57 & 21 \\
\hline & & E & 44.5 & 0.24 & 1.04 & 2.0 & 0.22 & 15 & 134 & 24 & 80 & 165 \\
\hline \multirow{5}{*}{$\begin{array}{l}\text { Mn-oxide-rich } \\
\text { mud }\end{array}$} & 3 & A & 2 & 1 & 85 & 61 & 5 & 9 & 24 & 13 & 13 & 2 \\
\hline & & B & 95 & 19 & 4 & 16 & 8 & 62 & 56 & 34 & 30 & 76 \\
\hline & & C & $<1$ & 60 & 1 & 12 & 49 & 10 & 4 & 51 & 14 & 4 \\
\hline & & D & 2 & 20 & 10 & 11 & 39 & 19 & 16 & 1 & 42 & 17 \\
\hline & & E & 28.4 & 1.37 & 6.2 & 1.5 & 1.2 & 13 & 175 & 95 & 182 & 104 \\
\hline \multirow[t]{5}{*}{ Nontronite } & 4 & A & 6 & $<1$ & 19 & 9 & $<1$ & 16 & n.d. & n.d. & 9 & 10 \\
\hline & & B & 42 & 1 & 38 & 13 & 8 & 33 & n.d. & n.d. & 7 & 20 \\
\hline & & C & 25 & 98 & $<1$ & 76 & 53 & 0 & n.d. & n.d. & 6 & 0 \\
\hline & & D & 27 & $<1$ & 43 & 2 & 40 & 50 & n.d. & n.d. & 78 & 70 \\
\hline & & $\mathrm{E}$ & 0.47 & 21.5 & 0.40 & 1.8 & 0.13 & 2 & n.d. & n.d. & 70 & 10 \\
\hline \multirow{5}{*}{$\begin{array}{r}\text { Transitional } \\
\text { sediment }\end{array}$} & 1 & A & 41 & 1 & 82 & 30 & 2 & 14 & 14 & 36 & 6 & n.d. \\
\hline & & B & 7 & 2 & 2 & 1 & 3 & 0 & 2 & 38 & 9 & n.d. \\
\hline & & C & 52 & 97 & 7 & 66 & 70 & 71 & 72 & 23 & 46 & n.d. \\
\hline & & D & 0 & 0 & 9 & 2 & 25 & 14 & 11 & 3 & 40 & n.d. \\
\hline & & E & 0.10 & 14.3 & 4.2 & 2.6 & 0.89 & 7 & 97 & 294 & 160 & n.d. \\
\hline \multirow{5}{*}{$\begin{array}{l}\text { Surface pelagic } \\
\text { sediment }\end{array}$} & 1 & A & 8 & 3 & n.d. & 53 & 3 & 6 & 1 & 0 & 18 & 3 \\
\hline & & B & 78 & 24 & n.d. & 5 & 4 & 50 & 66 & 27 & 16 & 63 \\
\hline & & C & 3 & 61 & n.d. & 29 & 62 & 38 & 22 & 73 & 34 & 33 \\
\hline & & D & 11 & 11 & n.d. & 13 & 30 & 14 & 10 & 0 & 32 & 0 \\
\hline & & $\mathrm{E}$ & 3.6 & 2.1 & n.d. & 0.79 & 1.1 & 8 & 67 & 142 & 180 & 30 \\
\hline
\end{tabular}

a See note to Table 1 for explanation of Fractions A-E.

higher than that of the muds. The $\mathrm{Cu}$ content of the muds is higher than in the crusts, and a greater percentage of it is $\mathrm{HCl}$-soluble; whereas in the crusts, most $\mathrm{Cu}$ is acid-reducible. Zinc, like $\mathrm{Cu}$, is more abundant in the muds, but its partitioning is not dissimilar in the two sample types, most $\mathrm{Zn}$ being in the more resistant fractions rather than in the acid-reducible (i.e., oxide-associated) fraction.

\section{Nontronite}

In the nontronites $\mathrm{Mn}$ is most abundant in Hole 509B and more of it is acid-reducible compared with Hole 506 nontronites, in which greater percentages of the total
$\mathrm{Mn}$ are acetic-acid and $\mathrm{HCl}$-soluble. Iron shows a very similar behavior at both sites, with the $\mathrm{Fe}$ in the nontronite being essentially completely soluble in $\mathrm{HCl}$. Magnesium and $\mathrm{Al}$ also show similar partitioning in the two holes. A larger carbonate component in Hole 506 nontronites compared to those from Hole 509B is indicated by the higher total $\mathrm{Ca}$ in the former and the greater percentage of it being acetic-acid soluble. Cobalt levels in the nontronite are too low to be able to assess the partitioning of this element with any degree of confidence. Much more $\mathrm{Zn}$ is $\mathrm{HCl}$-resistant in Hole 509B nontronites than in those from Hole 506, where more $\mathrm{Zn}$ is acidreducible and $\mathrm{HCl}$-soluble. 


\section{Transitional Sediments}

The transitional sediments $\mathrm{Fe}, \mathrm{Mg}, \mathrm{Ca}$, and $\mathrm{Al}$ behave similarly in both holes. However, Mn does show some differences, there being somewhat less total Mn in the sediment from Hole 509B while a greater percentage of it is $\mathrm{HCl}$-soluble. Hole 506 samples contain more acetic acid-soluble $\mathrm{Ni}$ than those from Hole 509B, in which more $\mathrm{Ni}$ occurs in the $\mathrm{HCl}$-soluble and $\mathrm{HCl}$-resistant fractions. Copper is much more abundant in the sample from Hole 509B and a higher percentage of the total $\mathrm{Cu}$ is acetic-acid soluble compared with Hole 506 samples. Total $\mathrm{Zn}$ is also higher in the Hole 509B sample, but the major difference between sites in this case is the higher percentage of $\mathrm{HCl}$-resistant $\mathrm{Zn}$ in the 509B sample.

\section{Surface Pelagic Sediment}

While the surface pelagic sediment at Hole 509B is much higher in $\mathrm{Mn}$ and $\mathrm{Fe}$ than that from Hole 506, these metals, and $\mathrm{Mg}$ and $\mathrm{Al}$ as well, show similar partitioning at both holes. In the sample from Hole 509B, more $\mathrm{Co}$ is present in the more resistant fractions than in that from Hole 506. More $\mathrm{Ni}$ and $\mathrm{Cu}$ are acetic-acid soluble in Hole 506 than Hole 509B, and the total Ni content of the former is higher. However, Hole 506 surface sediment contains less $\mathrm{Cu}$ than that from Hole $509 \mathrm{~B}$, in which sample most of the $\mathrm{Cu}$ is $\mathrm{HCl}$-soluble rather than acetic-acid soluble. The relative proportions of $\mathrm{Zn}$ and $\mathrm{Pb}$ which are acetic acid-soluble are also higher at Site 506 than in Hole 509B, where, by contrast, these metals are more concentrated in the $\mathrm{HCl}$-soluble and $\mathrm{HCl}$-resistant fractions.

\section{VARIATIONS IN GEOCHEMICAL PARTITIONING WITH DEPTH}

In order to assess variations in geochemical partitioning with depth in each hole, the proportions of each element associated with each fraction were plotted against depth. $\mathrm{Ca}, \mathrm{Co}, \mathrm{Ni}, \mathrm{Cu}, \mathrm{Zn}$, and $\mathrm{Pb}$ showed no consistent trends and are not considered further, but $\mathrm{Fe}$, $\mathrm{Mn}, \mathrm{Mg}$, and $\mathrm{Al}$ do show significant trends and these are shown in Figure 1.

In both holes, significant variations in the partitioning of $\mathrm{Fe}$ are found in the upper 10 meters, while below this depth its partitioning is more constant (see Fig. 1). Generally there is a trend for acid-reducible $\mathrm{Fe}$ to decrease with depth in both holes from the surface down to 10 meters, while $\mathrm{HCl}$-soluble $\mathrm{Fe}$ increases downwards over this interval.

Manganese shows greater variations in partitioning with depth in both holes than does Fe (Fig. 1). The variations are largely the result of the varying amounts of Mn-oxides present, these being completely soluble in the acid-reducing agent. Thus the peaks in acid-reducible $\mathrm{Mn}$ in the upper part of each hole coincide with the horizons at which Mn-oxide-rich sediment occurs. However, overlying these marked peaks there is a general trend in both holes toward a decrease in acid-reducible Mn with increasing depth over the uppermost 10 meters or so of sediment. There is also a definite increase in the propor- tions of Mn which are acetic acid-soluble from about 10 meters sub-bottom toward the base of each hole.

Magnesium also shows marked variations in partitioning in the upper 10 meters of sediment at each hole. In both holes acetic acid-soluble $\mathrm{Mg}$ decreases downward throughout the uppermost 10 meters, then increases again toward the bottom of the hole. Acid-reducible $\mathrm{Mg}$ shows a decrease with depth in both holes, very similar to that seen for $\mathrm{Mn}$.

The main trend in $\mathrm{Al}$ partitioning in both holes is an increase in $\mathrm{HCl}$-soluble $\mathrm{Al}$, at the expense of $\mathrm{HCl}$-resistant $\mathrm{Al}$, with increasing depth.

\section{DISCUSSION}

The data presented here and the patterns observed enable us to address several questions pertaining to the geochemistry of those sediments forming the hydrothermal mounds.

An important feature of the deposits is the similarity in the partitioning of most elements in each sample type in both holes. Some differences do occur, however. In particular, regardless of the differences in the total amounts present, the trace metals $\mathrm{Co}, \mathrm{Ni}, \mathrm{Cu}, \mathrm{Zn}$, and $\mathrm{Pb}$ all show some evidence of being present to a greater extent in the more resistant fractions (i.e., $\mathrm{HCl}$-soluble and $\mathrm{HCl}$-resistant) in samples from Hole 509B than in those from Hole 506. The trend is not marked, and different elements exhibit it in the different sample types recognized, which makes any possible explanation difficult. In most cases the $\mathrm{Al}$ partitioning and total $\mathrm{Al}$ content are similar in samples of the same lithology from the two different holes. This indicates that the differences in trace metal partitioning are not likely to result simply from variations between the holes in the type or amount of aluminosilicate material present.

The hydrothermal Mn-oxide is completely dissolved by the acid and reducing agent attack while the hydrothermal Fe phase (i.e., nontronite) is dissolved by the $\mathrm{HCl}$ attack, and any trace metals associated with these phases will be present in the corresponding fractions. Although data for $\mathrm{Ni}$ and $\mathrm{Cu}$ in nontronites from Hole 509B are lacking, it is clear from Table 1 that the hydrothermal Mn-oxides contain more $\mathrm{Co}, \mathrm{Ni}, \mathrm{Cu}, \mathrm{Zn}$, and $\mathrm{Pb}$ than the nontronites and that these metals are less associated with the hydrothermal phases in samples from Hole 509B than in those from Hole 506. It is not possible to ascertain directly the source of these metals using partition geochemical studies. However, the Mnoxide crust is likely to develop only at the sediment/water interface while nontronite formation may proceed largely at depth (Moorby and Cronan, this volume). Thus, although seawater might possibly be a source of trace metals for the Mn-oxides, it is not likely to be so for the nontronites. Since both these sediment types show the same trend of trace-metal depletion, both lithologies may well share the same major source of trace metals, which is therefore likely to be hydrothermal solutions. Levels of trace metals in Hole 509B samples are likely, therefore, to be lower either because of lower levels in the hydrothermal solutions supplying this 

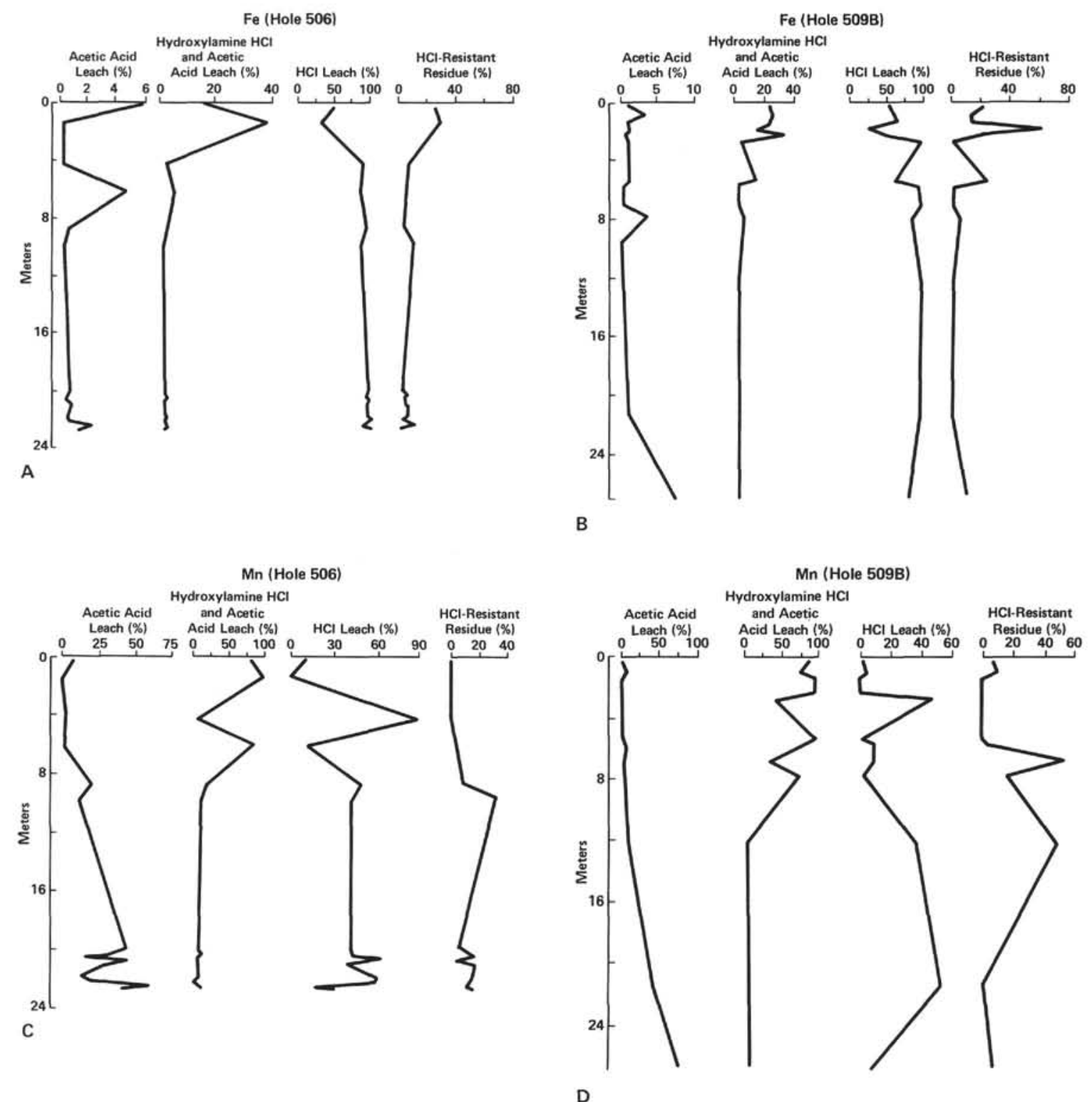

Figure 1. Vertical partition variations of $\mathrm{Fe}, \mathrm{Mn}, \mathrm{Mg}$, and $\mathrm{Al}$ in Holes 506 and 509B. (Results are expressed as percentages of the total concentrations.)

mound, or, perhaps more likely, because of differences in the rate of accumulation of the deposits, a faster accumulation rate allowing less time for scavenging and incorporation of trace metals into the hydrothermal phases.

The extremely low levels of $\mathrm{Co}, \mathrm{Ni}, \mathrm{Cu}, \mathrm{Zn}$, and $\cdot \mathrm{Pb}$ in the hydrothermal phases suggests that levels of these metals are probably very low in the hydrothermal solutions supplying the deposits and that accumulation of the phases is rapid. Although levels of all the trace metals are very low, $\mathrm{Pb}$ shows evidence of significant hydrothermal supply compared to $\mathrm{Co}, \mathrm{Ni}, \mathrm{Cu}$, and $\mathrm{Zn}$ (cf. Varnavas and Cronan, 1981). It is much more concentrated in the Mn-rich muds and crusts than in the pelagic ooze. The reverse tends to be true for the other trace metals.
It can be seen from Figure 1 that $\mathrm{Mn}$ is rather more variable in its partitioning than the other elements. One particularly interesting feature of $\mathrm{Mn}$ partitioning in both holes is the increase upward in acid-reducible $\mathrm{Mn}$ in the upper 8 to 10 meters of sediment. This Mn represents that present in oxides, and therefore as $\mathrm{Mn}^{4+}$. The uppermost oxidized zone in the pelagic sediments in this area persists to no deeper than $30 \mathrm{~cm}$ (see site reports), and the presence of $\mathrm{Mn}$ as an oxide below this level in the mounds is therefore interesting. Below about $10 \mathrm{me}$ ters in both holes, $\mathrm{Mn}$ becomes increasingly present in a more soluble form with increasing depth, being removed by acetic acid; this feature complements the behavior of this element above 10 meters depth. Thus the amount of $\mathrm{Mn}$ in a more soluble form, presumably as $\mathrm{Mn}^{2+}$, decreases upward in the lower part of the 

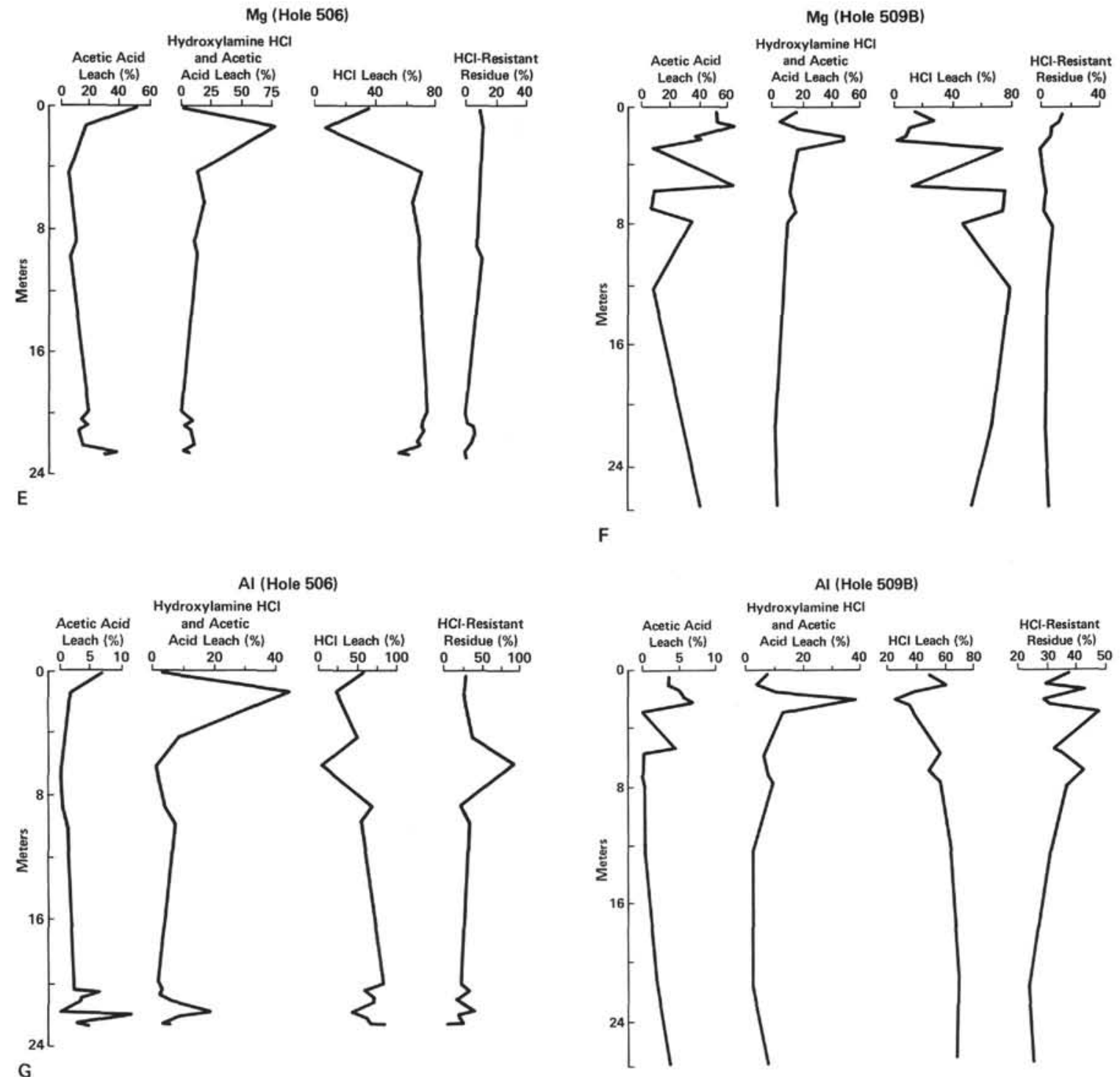

Figure 1. (Continued).

mounds, until, above 8 to 10 meters below the mudline, amounts become almost zero and, instead, Mn becomes increasingly abundant upward (particularly in Hole 509B) and present as more insoluble $\mathrm{Mn}^{4+}$, in Mn-oxides. This trend in Mn partitioning has an important bearing on mounds formation and will be discussed again later.

Because both the nontronite and other authigenic and detrital Fe-bearing phases may be wholly or partially dissolved by the $\mathrm{HCl}$ attack, the partitioning of $\mathrm{Fe}$ in the mounds does not necessarily reflect only trends resulting from variations in the pattern or mode of nontronite formation. However it is noticeable that only in the upper 8 to 10 meters in each hole are significant amounts of $\mathrm{Fe}$ acetic-acid soluble or acid-reducible. The $\mathrm{Fe}$ in these fractions is likely to be present either as a discrete noncrystalline $\mathrm{Fe}$-oxide or within the acid-reducible $\mathrm{Mn}$ oxides.

Apart from being a critical interval for $\mathrm{Mn}$ and $\mathrm{Fe}$ partitioning, two other parameters show a marked

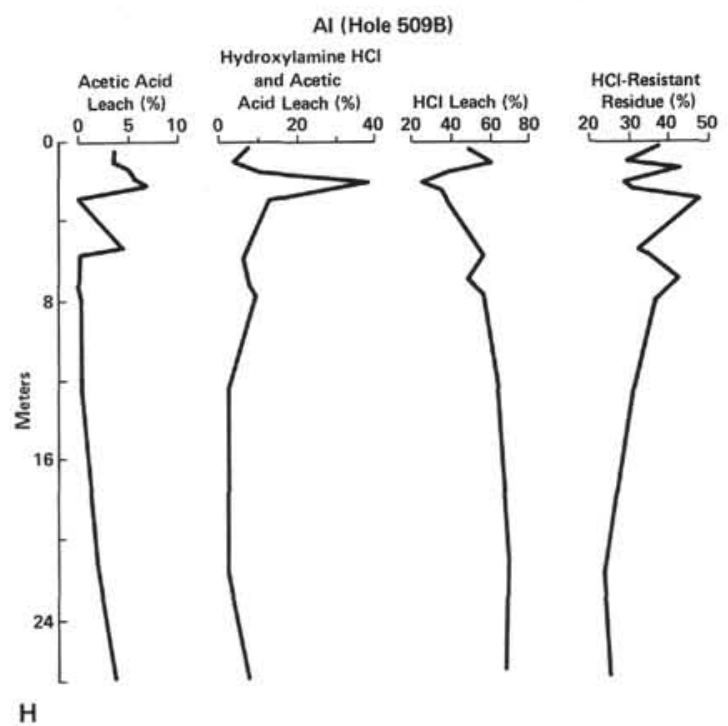

change at about 8 to 10 meters below the mudline. Levels of $\mathrm{Fe}$ in the pore waters fall off markedly above this level (see Bender, this volume). This feature, combined with the change in Fe partitioning, strongly suggests that at about this level conditions become oxidizing enough to precipitate $\mathrm{Fe}$ out of solution as ferric oxyhydroxides. The other parameter which changes at this interval is the biogenic silica content of the sediments, which falls to virtually zero below this level, even in the pelagic sediment layers (see site reports). This may be fortuitous since $\mathrm{SiO}_{2}$ solubility is much more sensitive to variations in temperature than redox potentials (Dapples, 1967 and references therein). Honnorez et al. (1981) in fact regard the dissolution of biogenic silica within the mounds as simply resulting from the upward flow through the mounds of warm, silica-poor hydrothermal solutions.

There are two ways in which the nontronite in the mounds can form. The first is by direct precipitation of an iron-silicate from solution (Harder, 1976), and the 
second is by the initial precipitation of separate ironoxyhydroxide and silica phases and their subsequent diagenetic transformation by a process such as that put forward by Heath and Dymond (1977). Visual evidence of the mounds themselves (see site reports) shows no evidence of an increase in nontronite with increasing depth and indeed pure nontronite has been observed at the sediment/water interface in the mounds (Williams et al., 1979). This argues against a slow diagenetic formation process for the nontronite. On the other hand, the direct precipitation of nontronite from solution requires low concentrations of the reactants and an Eh which is zero or slightly negative (Harder, 1976), and this argues for nontronite formation at depth in the mounds sediments. Analyses have shown that almost all the $\mathrm{Fe}$ in the nontronites is present as $\mathrm{Fe}^{3+}$ (Moorby and Cronan, this volume). Since $\mathrm{Fe}^{3+}$ is highly insoluble except in very acidic solutions, the hydrothermally supplied $\mathrm{Fe}$ must be in the form of $\mathrm{Fe}^{2+}$, and (notwithstanding the need for an overall 0 to slightly negative $\mathrm{Eh}$ ), an oxidation process must therefore be put forward to explain nontronite formation. Honnorez et al. (1981) proposed the following reaction:

$$
4 \mathrm{Fe}^{2+}+8 \mathrm{SiO}_{2}+\mathrm{O}_{2}+6 \mathrm{H}_{2} \mathrm{O} \rightarrow \mathrm{Fe}_{4} \mathrm{Si}_{8} \mathrm{O}_{2}(\mathrm{OH})_{4}+8 \mathrm{H}^{+}
$$

These authors also indicate that the necessary oxidant may be dissolved $\mathrm{O}_{2}$ or $\mathrm{NO}_{3}{ }^{-}$or $\mathrm{MnO}_{2}$. The presence of these oxidants in sufficient amounts must, therefore, set a lower limit to the depth at which nontronite can form. For $\mathrm{O}_{2}$ and $\mathrm{NO}_{3}-$ calculations show that the nontronite would need to form within a few centimeters of the surface (Honnorez et al., 1981), but, as has been shown, $\mathrm{Mn}$-oxides are present within the mounds at depths considerably exceeding this. Reduction of buried Mn-oxides may therefore be the main mechanism of nontronite formation in the mounds. The lower limit of the presence of Mn oxides in the mounds, as shown by the partition data, would therefore set a lower limit for the depth at which nontronite formation can occur.

At both the holes studied, the partition patterns of $\mathrm{Mg}$ and $\mathrm{Al}$ show much more variability in the upper 10 meters of sediment than lower down in the holes. In the $\mathrm{Mn}$-rich facies, $\mathrm{Mg}$ is mainly in the acid-reducible fraction and is therefore incorporated in the Mn oxides. $\mathrm{Mg}$ can also be incorporated in the nontronite crystallographic lattice (Donnelly, 1980), and in this sediment most $\mathrm{Mg}$ is $\mathrm{HCl}$-soluble. In the pelagic sediments, total $\mathrm{Mg}$ levels are much lower, most $\mathrm{Mg}$ being present as salt water evaporates and is acetic-acid soluble. These sediment types are most variable in their occurrence in the uppermost 8 to 10 meters of the two holes, particularly in Hole 509B, and this increased lithological variability largely explains the variations in $\mathrm{Mg}$ partitioning over this interval.

Aluminum and $\mathrm{Fe}$ show some similarity in partitioning in the $\mathrm{HCl}$-soluble and $\mathrm{HCl}$-resistant fractions in the uppermost 10 meters of each hole. The percentage of the respective totals of each element present in the $\mathrm{HC1}$ soluble fraction decrease upward while there is a corresponding increase upward in the amounts resistant to $\mathrm{HC}$. These partition patterns suggest that in all sediment types including nontronite, some $\mathrm{Fe}$ is present in detrital aluminosilicate material. The reason for the trends seen in the uppermost 10 meters is not clear, but the increased solubility in $\mathrm{HCl}$ of $\mathrm{Al}$-bearing phases with depth may indicate diagenetic changes with depth.

\section{REFERENCES}

Andrews, A. J., Dollase, W. A., and Fleet, M. E., in press. A Mössbauer Study of Saponite in Layer 2 basalt, Deep Sea Drilling Project Leg 69. In Cann, J. R., Langseth, M. G., Honnorez, J., Von Herzen, R. P., White, S. M., et al., Init. Repts. DSDP, 69: Washington (U.S. Govt. Printing Office).

Chester, R., and Hughes, M. J., 1967. A chemical technique for the separation of ferromanganese minerals, carbonate minerals and adsorbed trace elements from pelagic sediments. Chem. Geol., 2: 249-262.

Cronan, D. S., 1976. Basal metalliferous sediments from the eastern Pacific. Bull. Geol. Soc. Am., 87:928-934.

Dapples, E. C., 1967. Silica as an agent in diagenesis. In Larson, G., and Chillinger, G. V. (Eds.), Developments in Sedimentology (Vol. 8): Amsterdam (Elsevier), 323-342.

Donnelly, T. W., 1980. Secondarily modified sediments of the eastern Pacific: Major element chemistry of Sites 420, 424, and 425, DSDP Leg 54. In Rosendahl, B. R., Hekinian, R., et al., Init. Repts. DSDP, 54: Washington (U.S. Govt. Printing Office), 329-338.

Goldberg, E. D., and Arrhenius, G., 1958. Chemistry of Pacific pelagic sediments. Geochim. Cosmochim. Acta. 13:153-212.

Harder, H., 1976. Nontronite synthesis at low temperatures. Chem. Geol., 18:169-180.

Heath, G. R., and Dymond, J., 1977. Genesis and transformation of metalliferous sediments from the East Pacific Rise, Bauer Deep and Central Basin, northwest Nazca Plate. Bull. Geol. Soc. Am., 88:723-733.

Honnorez, J., Von Herzen, R. P., Barrett, T. J., Becker, K., Bender, M. L., Borella, P. E., Hubberten, H.-W., Jones, S. C., Karata, S., Laverne, C., Levi, S., Migdisov, A. A., Moorby, S. A., and Schrader, E. L. Hydrothermal mounds and young ocean crust of the Galapagos: Preliminary Deep Sea Drilling results, Leg 70. Geol. Soc. Am. Bull., 92:457-472.

Varnavas, S. P., and Cronan, D. S., 1981. Partition geochemistry of sediments from DSDP 424 in the Galapagos Hydrothermal Mounds Field. Mineralog. Mag., 44:325-331.

Williams, D. L., Green, K., van Andel, Tj. H., Von Herzen, R. P., Dymond, J. R., and Crane, K., 1979. The hydrothermal mounds of the Galapagos Rift: Observations with DSRV "Alvin"' and detailed heat flow studies. J. Geophys. Res., 84:7467-7484. 